\begin{tabular}{lllll}
\hline Estudios de Economía A Alicada & Vol. $32-1$ & 2014 & PÁgs. $111-138$ \\
\hline
\end{tabular}

\title{
Perspectivas económicas de Goya
}

\section{VICENT LLOMBART}

Universidad de Valencia, Facultad de Economía, Avda. de los Naranjos, s/n, 46022 Valencia, España. E-mail: vicent.llombart@uv.es

\section{RESUMEN}

El objeto del trabajo es una primera aproximación a los aspectos económicos de la pintura y los grabados de Francisco de Goya, penetrando en su significado, en su relación con la realidad de su tiempo y en su posible correspondencia con las ideas económicas de los ilustrados españoles. Se hace una selección de las más destacadas obras sobre agricultura, industria y comercio y otros aspectos como los retratos de economistas y los ingresos monetarios del pintor, y se analizan las dificultades en integrar estrictamente las ideas económicas y el complejo proceso artístico.

Palabras clave: Economía y arte, Goya, agricultura, industria, comercio.

\section{Economic Perspectives of Goya}

\begin{abstract}
The purpose of this paper is a first approximation to the economic aspects of painting and engraving by Francisco de Goya, penetrating in its meaning, its relationship with the reality of their time and their possible correspondence with economic ideas of the Spanish Enlightenment. A selection of the most outstanding works on agriculture, industry and trade and other aspects such as the portraits of economists and monetary income of the painter is done, and the difficulties are discussed in strictly economic ideas and integrate the complex artistic process. Last, we see the difficulties in integrating the economic ideas and the complex artistic process.
\end{abstract}

Keywords: Economics and Art, Goya, Agriculture, Industry, Trade.

Clasificación JEL: A1, B1, Z11

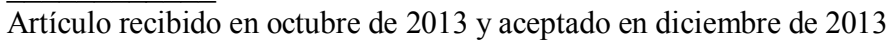

Artículo disponible en versión electrónica en la página www.revista-eea.net, ref. ə-32119 


\section{INTRODUCCIÓN}

El objeto principal del presente ensayo es ofrecer una primera aproximación al estudio de los aspectos económicos de las pinturas y grabados de Francisco de Goya (Fuendetodos 1746 - Burdeos 1828). Trataremos de penetrar en el significado de las obras, en su relación con la realidad de la época y en su posible correspondencia con las ideas económicas de los ilustrados españoles. En la multitud de imágenes creadas por el pintor aragonés, las obras a las que se les puede atribuir un significado económico constituyen una pequeña parte. Realizaremos, pues, una selección de las imágenes que lo manifiesten con mayor claridad relacionadas con la agricultura, con la "intelectualización agraria" europea, con la miseria del campesinado, con la industria, con el trabajo en general y al femenino en particular y con el comercio exterior. Otros aspectos: son los retratos de escritores económicos y los ingresos monetarios del propio pintor. Goya, un pintor extraordinario y "caprichoso", manifiesta unas perspectivas económicas que resultan dignas de atención para apreciar el horizonte intelectual del propio artista, para observar el posible enlace entre arte y economía y para advertir la difusión de las ideas económicas en el siglo XVIII.

\section{ARTE, PINTURA Y ECONOMÍA}

Desde mitad del siglo XX hasta la actualidad se han desarrollado de forma independiente dos fenómenos intelectuales relevantes para el presente trabajo. En primer lugar, el pleno abandono de la leyenda tradicional que presentaba al pintor y grabador Francisco de Goya y Lucientes como hombre de capa y espada, persona inculta, impetuosa e intermitentemente trastornada. Leyenda descartada en numerosos estudios que han documentado la participación y simpatía de Goya con los ilustrados y con sus ideas, además de mostrarle como observador agudo de la realidad socio-económica y política española, y como crítico mordaz de actitudes, prejuicios e ignorancias de la época. ${ }^{1}$

Y en segundo lugar, el avance académico de la "economía del arte" como subárea de conocimiento especializada en el seno de la ciencia económica, producido principalmente desde el libro de William Baumol y William Bowen (1966) $;{ }^{2}$ un avance a menudo presentado en el marco de la "economía de la cultura". Es cierto que existió atracción de los economistas del siglo XVIII y principios del XIX por el arte, pero al considerarlo, con la excepción de Jeremy Bentham, como una actividad lujosa, improductiva o estéril no formó un campo específico de estudio y desde luego no experimentó el intenso incremento de la literatura de las últimas décadas. Fueron Alfred Marshall, Lord Robbins y John Maynard Keynes, entre finales del siglo XIX y la primera mitad del XX,

\footnotetext{
${ }^{1}$ Pérez y Sayre (1988, 6-12); Baticle (1992, 9-20); Helman (1986, 94-112).

${ }^{2}$ Baumol, William and William Bowen (1966).
} 
quienes subrayaron la importancia de los bienes artísticos y culturales para la civilización y bienestar humanos: unos bienes que estimulaban la formación, proporcionaban placer al observador y contribuían a una vida mejor. ${ }^{3}$ A partir de Baumol y Bowen se continuó y amplió esa perspectiva en la dirección de aplicar las herramientas del análisis económico al estudio de los aspectos económicos y monetarios de las actividades artísticas, a la vinculación entre arte y mercado, a la oferta, demanda y precios de los bienes artísticos, a los ingresos de los artistas, a la inversión y financiación pública de las artes, y a otros temas generales referidos a la creación, distribución y consumo de los bienes y servicios artísticos o al impacto económico del arte y la cultura en otros sectores. ${ }^{4}$

Este trabajo se sitúa en un punto intermedio entre la historia de las ideas económicas, la historia del arte y la economía del arte. Los dos primeros tipos de conocimiento son necesarios para proceder a la investigación de la obra de un autor cuyo valor artístico está analizado y calificado inicialmente por la historia del arte y, en su caso, de las ideas. Al enlazar las perspectivas económicas con las actividades artísticas en el caso de Goya, el ensayo conecta con aspectos de la "economía del arte" que hemos indicado. Sin embargo, es una relación peculiar pues se trata de un ejercicio histórico referente al siglo XVIII y no utilizamos el modelo de elección racional neoclásico que se ha hecho frecuente en esa clase de análisis, ni tampoco los modelos teóricos y estéticos de la historia del arte. ${ }^{5}$ Quizá podríamos situarlo en una línea de extensión de la "economía del arte" en su vertiente pictórica.

Respecto a Goya debemos avanzar que además de un pintor y grabador extraordinario, según historiadores, críticos y observadores, fue atento observador de la sociedad, de la economía, de la cultura y la política españolas, censor de errores y extravagancias de aristócratas, eclesiásticos y hombres en general, y fustigador de prejuicios e ignorancias. Además formó parte del mundo cultural y de instituciones como las Reales Academias de San Fernando y la de San Carlos, la Real Sociedad Económica Aragonesa (que le concedió una beca para su estancia italiana) y del Banco de San Carlos del que fue accionista y de diversas tertulias. Constituyó así un testigo destacado e implicado en la tormentosa época entre dos siglos transcurrida desde la explosión de la Revolución francesa hasta el fallecimiento del aragonés en el exilio de Burdeos en $1828 .{ }^{6}$

Tratamos de dilucidar, en la medida de lo posible, si las pinturas y grabados

\footnotetext{
${ }^{3}$ Goodwin (2006, 45-52).

${ }^{4}$ Frey ha considerado sólo una clasificación doble: estudios empíricos sobre arte y aplicación de la metodología neoclásica de la elección racional. Pensamos que la clasificación es estrecha y no recoge las divesas investigaciones que se están publicando y desarrollando.

${ }^{5}$ Pueden verse para esta y para la anterior nota, algunos modelos en Frey (2000, 9-32).

${ }^{6}$ Baticle (1992, 101-320) y Hughes (2004, 247-410).
} 
de Goya (o algunos de ellos) expresan visiones relevantes sobre la realidad económica de su tiempo, qué relaciones pueden tener con las ideas económicas existentes y qué incidencia experimentarían en la época y en el futuro. ${ }^{7}$ Se trata de una primera aproximación: la obra de Goya es extensa (unas 500 pinturas, 300 grabados e innumerables dibujos), ${ }^{8}$ y además en la inmensa bibliografía sobre el pintor no existe, o no he logrado encontrar, un estudio monográfico sobre el tema presente. Algunas referencias sugerentes, normalmente breves, se encuentran en trabajos sobre influencias o relaciones entre la literatura ilustrada y la obra de Goya: Lafuente (1947), Helman (1970 y 1986, 94-112), Glendinning (2008, 34-41 y 83-118), Nordström (1962, 116-170) y Tolimson (1993. 120-206). El sólido libro de Roberto Alcalá Flecha: Literatura e ideología en el Arte de Goya ${ }^{9}$ contiene varias observaciones socio-económicas y políticas de interés, pero está dirigido también a determinar el conjunto de las fuentes literarias del pintor.

El marco general del estudio de las imágenes de Goya se puede encabezar con la afirmación del distinguido especialista, Nigel Glendinning $(2008$, 35), recientemente fallecido: Goya "inventa las imágenes que encarnan las ideas y sugiere lo que debería sentirse al respecto al añadir luz y color". Se pregunta Glendinning si la ideología es de Goya o sólo lo son el arte y la imaginación; o si la ideología viene determinada o no por los encargos que recibe para realizar muchas de sus obras. La contestación del autor a esta cuestión importante es moderadamente positiva, al considerar que al menos parte de la ideología tenía el respaldo de Goya y que los contemporáneos reconocían la calidad de sus ideas y no sólo de su imaginación. ${ }^{10}$ Desarrollaremos ese enfoque en el último apartado.

Ante la amplitud y variedad de la producción artística de Goya y de la escasez de estudios previos sobre sus perspectivas económicas, es preciso, como hemos señalado, realizar una selección de las pinturas y los grabados más apropiados que presentamos a continuación en las cuatro categorías de la obra de Goya. Aunque en alguna ocasión entrelazados para algún tema específico. Las cuatro categorías serían: las alegorías y pinturas, los cartones para tapices, las estampas de los Caprichos, los dibujos y además una alusión a los retratos de

\footnotetext{
${ }^{7}$ Ortega y Gasset destacó por primera vez su "instintiva receptividad" respecto a las ideas contemporáneas que Goya filtraba y asimilaba en un proceso de creación propio, caracterizándolo como un pintor sintónico de las concepciones, expresiones y realidades de su entorno. En este ensayo nos preguntamos si fue también sintónico con los asuntos e ideas económicas. Ortega y Gasset $(1966,27)$.

${ }^{8}$ Estas cifras son aproximadas. Existen diferentes catálogos de las obras de Goya, que hemos utilizado además de otras fuentes: Morales (1994) y Gudiol (1985).

${ }^{9}$ Alcalá (1988).

${ }^{10}$ Glendinning (2008, 35-6).
} 
economistas y hombres de negocio Así pretendemos ofrecer una aproximación económica inicial pero que abarque a los principales tipos de pintura de Goya.

\section{UNA AGRICULTURA IDEALIZADA}

Cuatro pinturas alegóricas de contorno circular sobre la agricultura, la industria, el comercio y la ciencia fueron encargadas por Manuel Godoy a Goya para decorar la bóveda situada ante la grandiosa escalinata del Palacio madri-

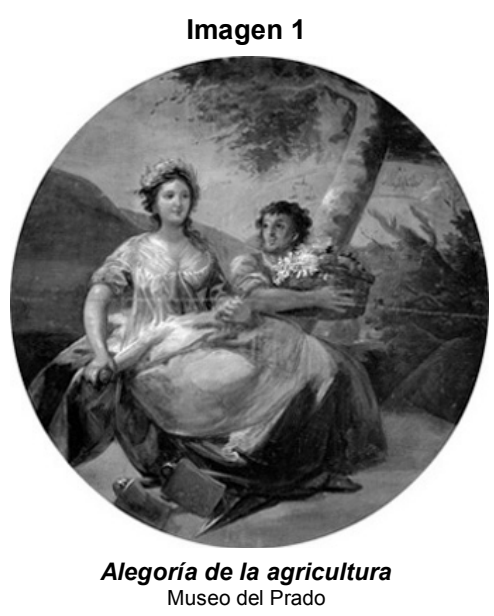
leño en que residía el valido desde su nombramiento como secretario de Estado en 1792, y que decidió restaurar y decorar con pinturas durante el periodo 1801-1805. Tras terminar la Guerra de las Naranjas con Portugal en 1801 y tras concluir Goya un conocido retrato del victorioso ministro (ubicado en la Academia de San Fernando), la nueva pretensión de Godoy con el encargo al aragonés de las cuatro pinturas era la ostentación política: obtener de un pintor de máximo prestigio unas imágenes alegóricas escenificando en la concurrida entrada del palacio los pilares del progreso económico y científico objeto de su supuesto espíritu reformador e ilustrado. Cabe indicar que la alegoría sobre la ciencia se encuentra desaparecida por lo que solo consideramos el análisis de las tres restantes, ubicadas en el Museo del Prado.

Ceres, la diosa romana de la agricultura, protectora de las tareas del ciclo agrícola e instructora de los hombres en el arte de cultivar la tierra, de sembrar y de recoger el trigo, aparece como figura central de la primera alegoría de Goya. Coronada por una guirnalda de espigas, como símbolo de fecundidad, y disponiendo a sus pies de dos azadones y una guadaña, como aperos de labranza, mantiene en la mano izquierda un racimo de uvas y unas espigas, y en la derecha una granada. Ligeramente detrás, un campesino muestra una cesta repleta de flores y frutos. Encima del campesino, a ambos lados del tronco del árbol, aparecen bosquejados los símbolos del zodiaco de libra y escorpio, correspondientes a los meses estivales y otoñales de la cosecha. ${ }^{11}$

La perspectiva de Goya sobre la agricultura en esta representación es una composición de estilo clásico donde la presencia destacada de Ceres idealiza, incluso diviniza, la actividad agraria. La ubicación prevista para la pintura y el

\footnotetext{
${ }^{11}$ Sobre las tres alegorías existen varias visiones distintas. Nos han sido de especial utilidad: Rose (1984, 34-39), Nordström (1962, 116-123), Tomlinson (1973, 126-132) y Baticle (1992, 186188).
} 
carácter de la demanda de Godoy al aragonés (aunque no se conserva documentación al respecto) pudieron influir naturalmente en la composición de ese mundo idealizado. Pero no cabe descartar en absoluto la existencia de una ideología agrarista en Goya que sintonizaba con la mayor parte de los escritores económicos y literarios de la Ilustración española (y de otros muchos del resto de Europa y de Norteamérica), ni tampoco de su conciencia de que en realidad el mundo agrario no era tan idílico como la alegoría representa.

Imagen 2

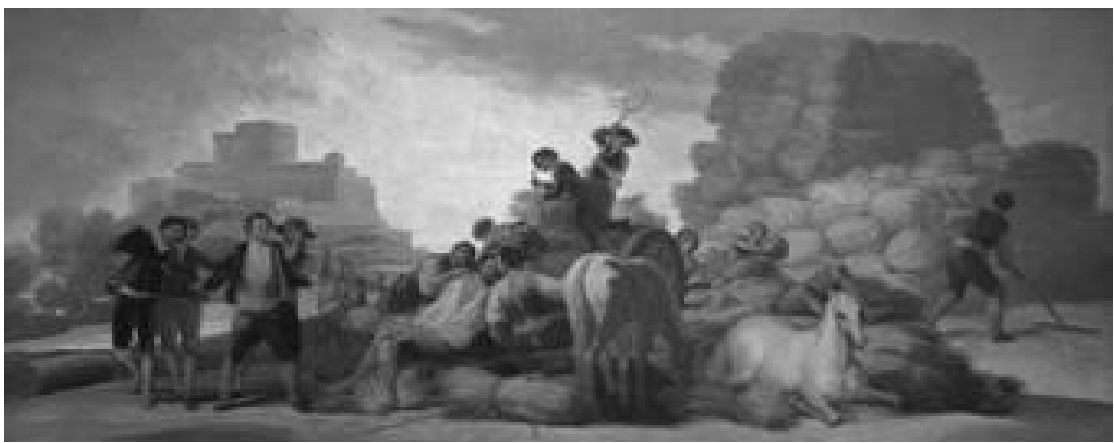

La era o el verano

Museo del Prado

La visión idealizada y un tanto bucólica de Goya sobre la agricultura se refleja también en algunos de los numerosos "cartones para tapices" que pintó desde 1775 hasta 1792 para la Real Fábrica de Tapices de Santa Bárbara, destinados a decorar las paredes de los palacios reales (El Escorial y El Pardo). ${ }^{12}$ De las variadas escenas sobre caza, diversiones populares, novilladas, temas costumbristas, oficios menores, personajes locales, seleccionamos para nuestra argumentación, por su contenido y significado, la serie de cuatro estaciones - $L a$ era o el verano, La vendimia o el otoño, La nevada o el invierno y La florera o la primavera- especialmente los dos primeros, que dibujó hacia 1786-1787, momentos en la que ya había adquirido cierta libertad de expresión pictórica y que eran -cabe subrayarlo- unos quince años anteriores a la Alegoría sobre la agricultura que hemos comentado. Ésta puede verse como una continuidad o culminación de los cartones. Nos centraremos en los dos primeros lienzos citados de la serie pues son los que contienen específicamente paisajes agrarios y

${ }^{12}$ Para valorar estas pinturas de Goya conviene tener en cuenta el proceso de realización de los llamados cartones. Primero se transmitían las medidas de la dependencia correspondiente desde la Casa Real al director de la Fábrica y las preferencias de sus titulares sobre los temas a desarrollar. Tras recibir el encargo de la Fábrica, el artista preparaba un boceto de tamaño reducido que, una vez aprobado, transformaba en un óleo o cartón de las mismas dimensiones que el tapiz final y que se tejería sobre él. Al final, los tapices se colgaban en las paredes previstas con molduras. Véase Arnaiz (1987, 14-15 y 173-176). 
revelan un mayor significado económico. ${ }^{13}$ La era o el verano muestra un atardecer estival en el que aparece una considerable cosecha de trigo agavillado y un conjunto de nueve trabajadores agrarios, con sus familias (y dos caballos) que descansan en los momentos de reposo y distracción tras la cosecha, $\mathrm{y}$ emprenden diversas actitudes joviales y amables (bebidas, niños jugando y comiendo, riendo bromeado, durmiendo...). Y a la derecha del lienzo otro agricultor continúa rastrillando la mies, quizá preparando la trilla.

El verano era el mayor de sus tapices $(278 \times 641 \mathrm{~cm})$ y Goya representaba la abundancia de la cosecha de trigo, el principal producto agrario, derivada del esforzado trabajo agrícola. Un trabajo que necesita unos tiempos de reposo y esparcimiento. Hombres y naturaleza gozan de las cosechas conseguidas y del descanso consiguiente. No hay contradicciones ni luchas en un campo dominado por el trabajo y el descanso. Se revela un ambiente afable y un tanto idílico en la cosecha y recolección del principal producto agrario. Recordemos también que ese fruto, el trigo, se encuentra así mismo en la cabeza y en la mano de la diosa Ceres de la Alegoría analizada y puede señalarse cierta relación. Como en el caso del signo del zodiaco de libra relativo al periodo estival.

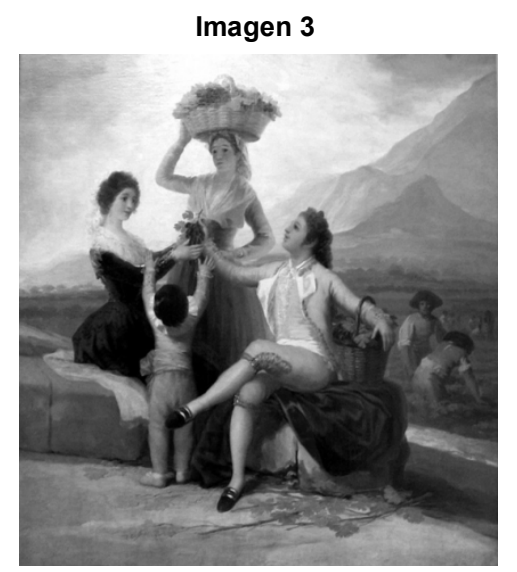

El otoño o la vendimia Museo del Prado

En el lienzo de la estación de El otoño se representa la actividad agrícola principal del periodo de la vendimia. Aparecen dos escenas, una galante y bien visible sobre el disfrute y consumo de la uva por una clase superior (quizá también propietaria de la tierra), y la otra con los trabajadores vendimiando como signo de la procedencia de la uva. En primer plano un joven y elegante majo, apoya su brazo izquierdo en una cesta llena de uvas negras y con el otro ofrece un racimo a una refinada dama sentada frente a él que acepta el ofrecimiento, adelantándose así a un niño que trata de atraparlo.

Por la vestimenta se observa que los tres personajes pertenecen a un estamento elevado (social superior). Tras ellos, una erguida campesina en actitud apática de espera, sujeta con su mano derecha un

\footnotetext{
${ }^{13}$ Sobre los otros dos cartones cabe indicar que La nevada, o El Invierno, se centra en el frío, la ventisca y la profusa nevada que padecen cinco caminantes que arrastran un mulo cargado con un cerdo sacrificado, mientras que Las floreras, o La Primavera, presenta una escena en la que una joven maja, entrega una rosa a la señora, mientras un campesino pretende sorprenderla con un conejo, símbolo también de la primavera. Ambos se encuentran el Museo del Prado junto con las dos anteriores.
} 
cesto repleto de racimos que lleva sobre la cabeza y que procede sin duda de la recolección.

A la derecha, en un plano inferior, se percibe la segunda escena del óleo: los trabajadores en la viña como productores y recolectores del estimado fruto. Dos vendimiadores en primer lugar y otros alejados ligeramente dibujados. Es curioso que uno de los dos primeros vendimiadores se esté alzando del encorvado trabajo y dirija la mirada sin disimulo alguno al grupo humano de la primera escena ¿No estará mostrando una prueba de reproche?

En todo caso, El Otoño representa en conjunto una imagen apacible y grata de la vendimia, en la que aparentemente no se dirimen dificultadas o bien se disponen éstas en segundo plano, como la relación entre los vendimiadores y los señores. El proceso de elaboración de este "cartón para tapiz", como el del anterior del verano, es hasta cierto punto similar al de la Alegoría de la Agricultura: existe un encargo de la Corte con el tema a desarrollar y las dimensiones del cartón, y además una supervisión inicial y final por parte de responsables de la Real Fábrica (Mengs, Bayeu). Aunque en todo caso la imagen a pintar no estaba predeterminada, existía un grado de libertad para el artista, que Goya aprovechó de forma creciente y variable en el tiempo. ${ }^{14}$ Ello nos permite hablar, a pesar de los condicionantes, de un agrarismo idealizador del propio de Goya. ${ }^{15}$

Tal idealización no era sólo un mero sentimentalismo ni tampoco un arte al puro servicio del poder. Aunque pueden existir matices y confusiones sobre ambos aspectos, hay que insertar las imágenes de Goya en su tiempo, en la situación existente y en las ideas predominantes, donde cobran un significado más real.

Se debe tener en cuenta que el Siglo de las Luces fue también el Siglo de la Agricultura. Europa y América estaban formadas por sociedades de base agrícola que giraban en torno al ciclo de las cosechas. ${ }^{16}$ En el caso español, la labranza y la ganadería ocupaban directamente dos tercios de la población activa y representaban más de un sesenta por ciento del valor de la producción total. Generaban los principales alimentos de la población, las rentas de la tierra de los propietarios, las materias primas a transformar por la industria y proporcionaban los objetos principales de las actividades comerciales. ${ }^{17}$

Así pues, el peso de la agricultura en la renta y la riqueza, en el trabajo y en la preeminencia social y política del terrateniente, era muy elevado. El bienestar

\footnotetext{
${ }^{14}$ Tomlinson (1993, 117-120).

${ }^{15}$ Existen otros cartones como El pescador de caña, Los leñadores, Los pobres en la fuente, La merienda a orillas del Manzanares y la Merienda campestre, que muestran indirectamente temas relacionados con la agricultura. Aunque no cambian la perspectiva agraria de Goya.

${ }^{16}$ Una visión general en Venturi (1969-1990).

${ }^{17}$ Pueden verse: Ocampo (2010, 96-100), Llopis (2002, 121-192); Sebastián (2004, 198-226).
} 
o malestar de las familias campesinas y de buena parte del resto de la población dependían de la situación agraria y de las expectativas de evolución. Además de ser el principal sector económico, daba pie a un tipo de vida, a unas actitudes y costumbres y, en conjunto, a una mentalidad extendida en la España y la Europa de la época de la Ilustración. No es extraño, pues, que los contemporáneos dedicaran una intensa atención a los asuntos del campo, intensificando la que ya se prestó en el siglo anterior (García Sanz 1996). En el siglo XVIII ensayistas y poetas, escritores económicos y políticos, pintores y científicos, nobles y clérigos, se dedicaron a pensar, deliberar, escribir, publicar y dibujar con distintos criterios sobre el agro español, el centro de la vida económica y social. ${ }^{18}$

En este proceso, denominado como «intelectualización de la agricultura» en el ámbito europeo, ${ }^{19}$ que transcurrió en España con intensidad desde Benito Feijoo hasta Meléndez Valdés y Gaspar de Jovellanos, podemos sintetizar cuatro puntos destacados: 1) elogio y supremacía de la agricultura; 2) crítica de la miseria del campesinado; 3 ) primacía económica y moral de la vida rural (del labrador independiente); y 4) denuncia ordenada de los obstáculos generales al desarrollo agrario y propuesta de reforma agraria (Jovellanos 1795; Llombart 2000). Elogiar la agricultura, e incluso idealizarla, no era incompatible con mantener una conciencia del atraso agrario. Para Benito Feijoo en su importante y divulgada Honra y provecho de la agricultura (1739) no "hay arte u ocupación alguna digna de más honra que la agricultura" y que de todas "las artes fueron autores los hombres; de la agricultura lo fue Dios" (Feijoo, 54). Esa especie de divinización del cultivo aparecía junto a la crítica a la nobleza ociosa y a la denuncia de la grave miseria de los labradores. Este planteamiento en una interpretación racionalizadora podríamos verlo como que el elogio o idealización de la agricultura muestra la capacidad máxima de desarrollo y bienestar con sus extensos efectos sociales favorables, situación alejada debido a las desfavorables condiciones en que se encontraba.

La aparente paradoja entre elogio de la agricultura y censura de las diversas condiciones en que efectivamente se desarrolla siguió manteniéndose a largo del siglo, incluso en autores con mayor formación económica. Para Bernardo Ward (1762) la agricultura era el fundamento sólido de la opulencia y Campomanes no se cansó de repetir que constituía la fuente principal de la riqueza, el determinante del crecimiento de la población y la «basa fundamental de los Estados» (1774-1775). En la misma dirección Pablo de Olavide, propuso un plan de reforma de la agricultura andaluza, y Moratín hijo, Antonio Ponz, Sisternes y Feliu, Pedro Sánchez, Lucas Labrada, Ignacio de Asso, Antonio

${ }^{18}$ Robledo (1993, 15-40), Fernández (1993, 305-312). Un panorama sobre la evolución de la literatura acerca de la agricultura, que supone una reformulación ilustrada del viejo tópico del "Menosprecio de la Corte y alabanza de la aldea", en Lorenzo (2002, 331-368).

${ }^{19}$ Guerci $(1988,57)$ 
Cavanilles y un largo etcétera, continuaron con tales principios agrarios y avanzaron observaciones experimentales. ${ }^{20}$

En el terreno literario se asiste a una reformulación ilustrada del viejo tópico del Menosprecio de Corte y alabanza de la aldea (Antonio de Guevara 1535), transformándolo en Mísero colono y noble ocioso o inútil. ${ }^{21}$ Juan Meléndez Valdés, poeta destacado del siglo, magistrado y amigo de Jovellanos y de Goya, manifestó con elocuencia y energía en repetidos poemas la alabanza de la agricultura, la superioridad de la vida rural y la miseria del campesinado. Siguiendo la estela de Feijoo consideraba que la honrosa agricultura era la "profesión primera" que había sido santificada por el mismo Dios. Incluso solicitaba amparo divino para evitar que el pobre se convierta en "vil esclavo" y para eliminar la desigualdad entre nobles y plebeyos, ambos hijos de Dios. No existía razón para el despilfarro, el vicio y la ociosidad de los nobles inútiles.

En el notable poema, "El filósofo en el campo" de 1794 -fecha coincidente con la terminación del Informe de Jovellanos- Meléndez recoge y acentúa sus ideas. Los campesinos se caracterizan por la utilidad de su labor y por la virtud de sus costumbres y sus acciones. Sustentan al Estado: la "mole de tributos carga / sobre su cerviz ruda". Mientras los nobles (o habitantes ciudadanos) se distinguen por el lujo escandaloso, la ociosidad inútil y la apropiación del producto del trabajo campesino. En realidad, de sus versos se desprendía la existencia de una doble dependencia: la nobleza depende económicamente del campesino que paga los mayores impuestos y genera los alimentos y otros materiales básicos para la vida ciudadana. Pero hay una dependencia inversa: el campesino depende jurídica y económicamente del noble propietario de la tierra y del hombre de ciudad como comprador de productos agrícolas. El campesino aunque virtuoso y útil padece una suerte esquiva y vive en la miseria -desnudo, escuálido, hambriento y encorvado. Exclama que "El pobre gime / bajo una carga que llevar no puede", palabras que recuerdan el capricho 42 de Goya (Tú que no puedes). En definitiva, Meléndez insiste más en la denuncia que en las acciones necesarias para superar los problemas, se concentra en la crítica del noble y del hombre urbano víctima del lujo y del vicio, en el rechazo de los privilegios de la nobleza y del clero, y en la necesidad de una justicia social. ${ }^{22}$

${ }^{20}$ Llombart (2000, 32-51) y Robledo (1983, 12-45). Una amplia recopilación de textos agrarios y agronómicos en Argemí (1988).

${ }^{21}$ Transformación estudiada por Elena de Lorenzo (2002, 331-368). También Alcalá (1988, $132-$ 150), describe el proceso.

22 Además de "El filósofo en el campo" (1794, II, 784-789) se podría ampliar el presente comentario con el análisis de los poemas de Meléndez: "La despedida del anciano" (1787, 1033-1034), "Mi vuelta al campo" (1797, 558-559), "Los aradores" (1814, tomo I, 388-389), "Las vendimias" (1786, tomo I, 395), publicados en Meléndez (1820). Aunque la visión económica de Meléndez no cambiaría. 
Otro autor literario con estrecha relación personal y de ideas con Goya fue el dramaturgo y poeta Leandro Fernández de Moratín. ${ }^{23}$

El Informe sobre la Ley Agraria de Gaspar Melchor de Jovellanos, publicado en 1795 por la Sociedad Económica Matritense, vendría a ser una culminación y una expansión del pensamiento agrario de la Ilustración al introducir sistemáticamente en la argumentación los principios económicos. Compartía con la tradición el elogio de la agricultura a la que consideraba en el Informe como primera fuente de la prosperidad de un país, principal fundamento de la población, de la riqueza privada y del poder del Estado. Pero discrepaba de los escritores anteriores al considerar que la agricultura española no estaba en "decadencia" sino en un "estado progresivo", que se debería estimular eliminando los "obstáculos al progreso agrario". Obstáculos políticos o provenientes de las leyes, morales o provenientes de las opiniones y físicos o provenientes de la naturaleza. Principalmente el interés propio de los agentes agrarios y la acción desreguladora del gobierno en la primera clase de obstáculos y la instrucción pública y las inversiones en infraestructuras en la segunda y tercera, conducirían al desarrollo agrario y al bienestar social. Esa reforma agraria general era su principal objetivo y constituía el auténtico remedio económico y político de los problemas agrarios.

Jovellanos subrayaba también la pobreza o miseria de los campesinos. Las atribuía a tres causas principales: la primera al peso de las contribuciones discriminatorias sobre la agricultura; la segunda, al hecho de que el campesino no disfrutaba del fruto de su trabajo sino que debía pagar una renta al propietario de la tierra y una exacción a la Iglesia, cuando el humilde campesino debería ser propietario del rendimiento de su trabajo, un factor fundamental en la creación de riqueza; y la tercera causa es más general: el avance y la mayor equidad en la agricultura favorecerá las condiciones de vida del campesinado. Hay cierta similitud con Meléndez pero con un tratamiento más profundo no sólo de denuncia o sólo descriptivo sino de carácter prescriptivo proponiendo medidas concretas a tomar para una reforma agraria, la verdadera solución a la miseria.

Agricultura repartida y virtud campesina iban de la mano. La preferencia de Jovellanos por la pequeña y mediana extensión del cultivo no sólo se explica por razones económicas y técnicas, sino que corresponde a su perspectiva idealizadora de la agricultura y la sociedad, al objetivo de mayor igualdad en la riqueza y a alcanzar una superior moralidad, asunto importante. "Una inmensa población rústica derramada sobre los campos, no sólo promete al Estado un pueblo laborioso y rico, sino también sencillo y virtuoso" afirmaba en el Informe (p. 28-29). Alejados de la corrupción y el lujo de las ciudades y concentrados por propio interés en pequeñas explotaciones, se generarían mayores

${ }^{23}$ Baticle (1992, 90-111 y 311-314), Alcalá (1988, 15-18). Helman (1970, 52-62). 
virtudes morales, familiares y cívicas, "que constituyen la felicidad de las familias, y la verdadera gloria de los Estados". ${ }^{24} \mathrm{Al}$ final, pues, presentaba una visión optimista sobre el futuro de la vida material y moral de los campesinos y sus familias, la mayor parte de la población.

Sintetizadas las tres visiones de Meléndez Valdés, Jovellanos y Goya sobre la agricultura, provenientes de los campos literario, económico y artístico respectivamente, podemos observar una especie de triángulo formado por tres autores destacados en sus respectivos ámbitos y que pertenecen a un espíritu agrarista de la Ilustración española y europea. Mantienen una sintonía, naturalmente no una identidad, en sus perspectivas agrarias. La principal diferencia en el tema agrario, según lo visto hasta aquí, radica en que Goya no reflejaba la miseria del campesinado sino una visión agraria más apacible. Hay que esperar a las imágenes de los Caprichos para que incorporase tal cuestión.

La Colección de estampas, de asuntos caprichosos, inventadas y grabadas al agua fuerte por Don Francisco Goya se ofreció a la venta en febrero de 1799, si bien por poco tiempo dadas las circunstancias políticas represoras. Después, en 1803 , ante la amenaza de la Inquisición, ${ }^{25}$ entregó todas las planchas y los 240 ejemplares disponibles al rey, con destino a la Real Calcografía, solicitando

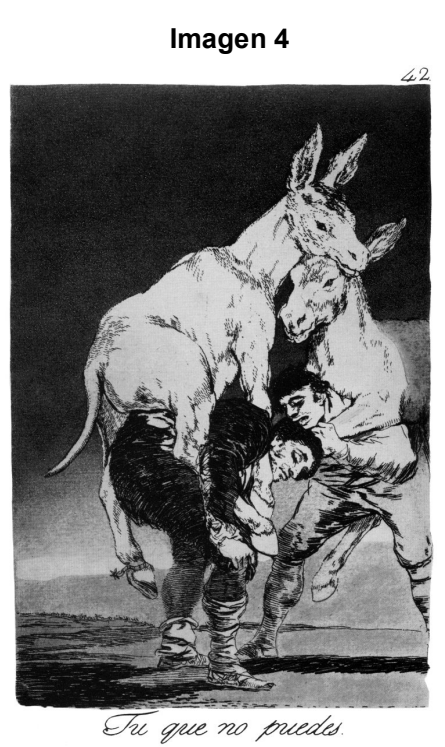

Tú que no puedes Capricho 42. Museo del Prado una pensión vitalicia para su hijo. ${ }^{1}$ Los ochenta caprichos (o sueños) que componían la colección suponían una multiplicación de las imágenes concebidas y se dirigían según el autor a censurar los errores y vicios humanos y a ejercitar la fantasía del artista. Una perspectiva libre de ataduras previas, satírica, moral y grotesca que a menudo desfigura la realidad para construir sus propias imágenes mentales. Variados fueron los temas abordados por Goya: la sátira de vicios (borrachera, gula, ociosidad, lujuria, vanidad, hipocresía); la inquisición, algunas órdenes eclesiásticas y el fanatismo religioso; el sueño de la razón y los monstruos; las asnerías; la educación; la miseria, la ignorancia y las supersticiones populares; la picaresca, los cortejos, la prostitución... Todos ellos formaban parte de la ideología de la Ilustración, pero independientemente de la sintonía con

\footnotetext{
${ }^{24}$ Jovellanos (1795, 28-29 y 146-147).

${ }^{25}$ Helman (1986, 46-59).
} 
Jovellanos, Meléndez Valdés y Fernández Moratín, el tratamiento de Goya fue peculiar y con ciertas implicaciones más allá de la herencia ilustrada.

En el Capricho 42, el anterior al famoso El sueño de la razón produce monstruos, dos míseros campesinos llevan a cuestas como bestias de carga a un par de miembros de las clases altas y ociosas (probablemente un noble y un fraile), que son presentados como dos asnos rollizos y animosos. El primero de ellos lleva una espuela en apariencia incisiva en la pata posterior izquierda, que muestra con claridad quién es el amo o señor y qué medios va a utilizar. Los campesinos sufren agobiados por la pesada sobrecarga. El título Tu que no puedes, primera parte de un conocido refrán que concluye llévame a cuestas, se refiere a lo que pensaban los ilustrados sobre la situación de los campesinos y las necesarias reformas condensadas en el Informe sobre la Ley Agraria de Jovellanos. ${ }^{26}$ Resalta la impotencia y la injusticia social de la que son víctimas los labradores, y representa a las clases ociosas como asnos mientras que a los campesinos con la dignidad de hombres. La lámina muestra un mundo doblemente invertido: entre los asnos como jinetes y los campesinos como animales de carga, y entre el ámbito del trabajo y la categoría social. El sistema económico carece pues de razón y de humanidad. ${ }^{27}$ Denunciada la cuestión, el Capricho parece dejar abierta la posibilidad de que criticando los males sociales, rebelándose contra ellos, se podrá lograr vencerlos por medio de la razón.

Imagen 5

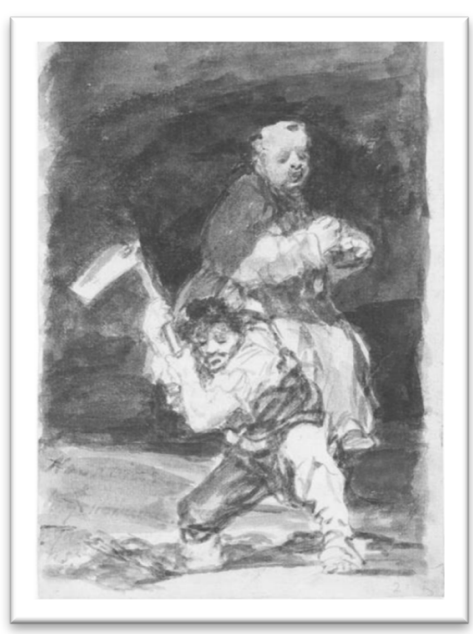

¿No sabías lo que llevabas a questas? Álbum C, 120. Hispanic Society
En un sentido similar, por si hubiera dudas sobre el significado anterior, se muestra el dibujo realizado en años posteriores: ¿No sabrás lo que llevas a cuestas?. Un nuevo campesino abrumado por el cansado trabajo de cavar la tierra y peculiarmente por el hecho de soportar en sus espaldas el peso de un grueso dominico -de la orden mendicante de predicadores- que come reposadamente de una escudilla. El dibujo viene a reconsiderar la imagen del Capricho 42, aunque de forma más explícita respecto al clero regular, causa de la miseria del campesino representado. El enfoque satírico y curioso de la estampa caprichosa adquiere en el dibujo un tono más áspero y directo derivado de la tensión entre el doble esfuerzo del campesino -cavar la

\footnotetext{
${ }^{26}$ Textos directos de Feijoo, Torres Villarroel, León de Arroyal, Manuel de Aguirre, Meléndez Valdés, Juan Pablo Forner, Jovellanos y otros, son reproducidos por Alcalá Flecha (1988 142146).

${ }^{27}$ Helman, (1986, 107).
} 
tierra y soportar al religioso- y la ociosidad y glotonería del fraile. La crítica a determinados comportamientos de los religiosos es una constante en su obra, siempre desde un espíritu reformador, no revolucionario. Uniendo ahora la estampa caprichosa y el dibujo, podemos considerar que expresan una crítica económica a la explotación campesina, una crítica política al papel de los dos estamentos superiores y una crítica a la organización social.

No harás nada con clamar es el título de otro llamativo dibujo de Goya, posterior a los Caprichos (Álbum E39, 180312) que plantea la cuestión del clamor campesino. En el dibujo un labrador que ha arrojado su azadón a tierra levanta los brazos, cierra los puños y abre bien la boca para exclamar a voz en grito la injusticia de su situación. No se deduce de la imagen hacia donde dirige su protesta; cabe considerar que hacia las clases aprovechadas o hacia el gobierno. Pero el título y la imagen nos dicen que la protesta no puede tener éxito, que no existe una posibilidad de cambio por esa vía. El por qué no se explica; quizá se sobrentiende dada le estructura económica, social y política de la sociedad española del siglo XVIII.

No es que Goya considere que no se debe Imagen 7

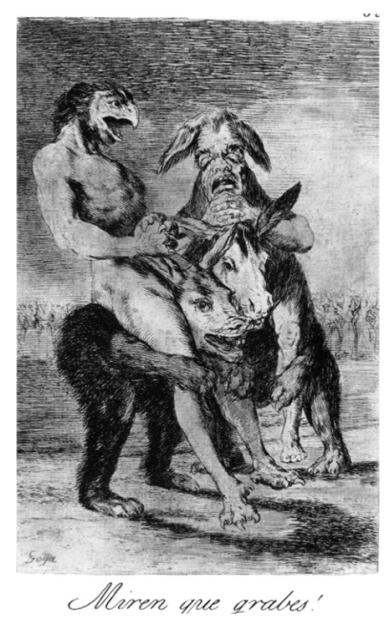

Miren qué grabes

Capricho 63. Museo del Prado manifestar la

protesta cam-

pesina, sino que será inútil. Aflora pues el pesimismo respecto al cambio en la grave situación agraria. Se podría considerar que existen otros caminos como la reforma agraria planteada al Consejo de Castilla por Jovellanos. Sin embargo, tampoco ese camino tuvo éxito efectivo, por lo que el pesimismo de Goya no deja de ser realista. En el fondo la visión de Goya duda de la capacidad de las ideas, de las denuncias, de los proyectos de reforma para combatir la miseria campesina y fomentar el progreso agrario y social.

En un sentido pesimista, pero con mayor desaliento y alcance sobre la propia naturaleza humana, había grabado Goya el extraño Capricho 63, ¡Miren qué graves! A menudo se presenta 
junto al Capricho 42, Tú que no puedes. Una composición hasta cierto punto similar, no puede ocultar las importantes transformaciones entre ambas imágenes. Los campesinos representados como hombres de carga en el primer Capricho son ahora animales parecidos a asnos peludos de grandes cabezas, mientras que los asnos que cabalgaban sobre los campesinos se han transformado ahora en personajes monstruosos: el primero con cabeza y garras en manos y patas de ave de rapiña y el segundo con expresión indolente, orejas de burro y actitud orante parece un animal devoto mantenido por los asnos subalternos. En el fondo de la nueva imagen una muchedumbre clama con fuerza, parece que contra esos personajes grotescos. Como afirma Helman $(1986,107)$ asistimos a la transformación de una estampa satírica, la del Capricho 42, en una caricatura grotesca, la del 63.

La conversión de los campesinos en bestias asnales y de los asnos sostenidos por los campesinos en personajes monstruosos es, a nuestro entender, lo más significativo del Capricho 63, Miren qué grabes [qué ilustres]. Las transformaciones entre las imágenes pueden deberse a la fantasía del grabador que expresa una mayor ruptura con la realidad, a un pesimismo creciente, que ya hemos indicado, con la reforma agraria y con las improbables medidas políticas a favor de los campesinos, a una visión crítica sobre la naturaleza humana y a la consideración de que la segunda imagen es como una derivación (no una contradicción) de la primera.

La última consideración merece un comentario. En el primer capricho los campesinos con gran esfuerzo mantienen a las clases superiores vestidas de asnos. La dura sobrecarga no parece tener fin: no estaba en manos de los labradores librarse de ella ni tampoco el gobierno iba a hacerlo. Así pues la situación de opresión y servidumbre se mantendría en el tiempo y era probable que degenerase (sobre todo) para los explotados campesinos y robusteciese a los aprovechados jinetes. La continuidad de la situación de vasallaje agravaría pues la libertad, la ignorancia, la ceguera y la capacidad de reacción de los labriegos que transformaría su propia naturaleza humana, convirtiéndose al final en una especie de asnos embrutecidos por sus condiciones de vida y el peso de la carga. Una visión cruel y pesimista que consigue con imágenes peculiares expresar duramente las contradicciones sociales en el campo agrícola que van más allá de la denuncias de los ilustrados.

Sin embargo, en la estampa final de los Desastres de la guerra (1810-15) Goya muestra un sorprendente aguafuerte, el número 82, Esto es lo verdadero, en el que vuelve (o quizá mantiene) a la alabanza de la agricultura. Después de mostrar los crueles horrores y la bárbara brutalidad de la Guerra de Independencia en 81 imágenes, introduce una más, la que culminaba la serie, con una visión esperanzadora en contraste con las anteriores. En la imagen, una bondadosa figura femenina coronada de ramas de olivo y ante un intenso resplandor, apoya 
la mano derecha de un largo brazo en el hombro del adusto campesino, encorvado, peludo (quizá una evolución de los campesinos-asno del Capricho 63) y con un azadón en la mano derecha. También el oscuro campesino apoya su mano izquierda en el hombro de la mujer; ambos apoyos parecen significar un entendimiento, una tarea común. El índice de la mano izquierda de la figura femenina apunta hacia varios productos de la cosecha agraria como un árbol frutal, unos fardos de trigo y otros artículos en una cesta a la que se acerca un perro.

La figura femenina es alegórica. Puede simbolizar la Verdad (como continuidad de los Desastres números 79 y 80 ) o mejor aún la Paz como deseo de concordia y vida próspera. En el contexto temporal de Goya, Verdad y Paz caminan juntas y se necesitan entre ellas. ${ }^{28}$ Alcanzada la paz en 1814, dando fin a

Imagen 8

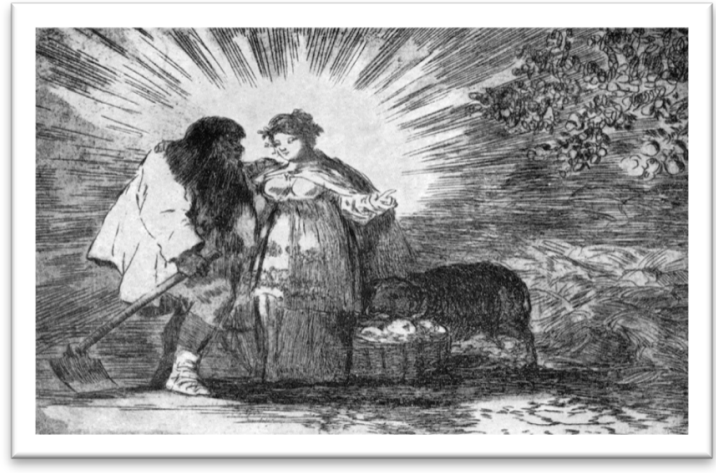

Esto es lo verdadero. Dibujo 82

Desastres de la guerra. Biblioteca Nacional la terrible Guerra de Independencia, la situación de ruina económica y fractura social de España requería una restauración. La agricultura, guiada por la diosa de la Paz, adquiría un papel esencial como base de la reconstrucción económica. A través de la Paz y del trabajo agrícola recuperado se podrá combatir el hambre, cubrir las necesidades y alcanzar un mayor bienestar. Lamentablemente la esperanza optimista de Goya no se extenderá al campo político al ser perturbada por las decisiones de Fernando VII de anular la Constitución de 1812 y de reimplantar un régimen absolutista represor. En todo caso, la confianza en la agricultura en un tiempo de crisis vuelve a surgir en esta imagen de madurez de Goya.

\section{LA INDUSTRIA: INCORPORACIÓN LABORAL DE LA MUJER Y DESTIERRO DE LA OCIOSIDAD}

Las alegorías de la industria y del comercio son composiciones circulares que, como hemos indicado, forman junto con la alegoría de la agricultura y de la ciencia (ésta última extraviada) una serie relativa a la evolución económica y

\footnotetext{
${ }^{28}$ La diosa griega de la Paz, Eirene, antecesora de la romana Pax, no solo significaba ausencia de la guerra, sino que se erige también como divinidad que alienta el ejercicio de la agricultura, incompatible con el estado de guerra. Es ante todo dispensadora de prosperidad y riqueza (Mirón Pérez, 2004, 9-12).
} 
científica española realizadas entre 1801 y 1805 , y destinadas al palacio de Godoy, personaje que efectuó el encargo a Goya para prestigiar su residencia y a sí mismo.

La industria representa a dos mujeres jóvenes que hilan con sus respectivas ruecas en una estancia iluminada por un amplio ventanal, bajo el que se perfilan tenuemente algunas cabezas femeninas observantes al parecer de la escena principal. Generalmente se considera que Goya se inspiró en el cuadro de Las Hilanderas o la Fábula de Aracne que Diego Velázquez pintó hacia 1657.Es posible, dado el alto aprecio que el pintor aragonés sentía por el sevillano, aunque no existen evidencias y entre ambos cuadros se observan notables diferencias. ${ }^{29}$ Los cerca de 150 años transcurridos entre ambas pinturas y el tema elegido permiten considerar dos opciones de interpretación más allá de la simple influencia velazqueña. En primer lugar, al tratar de representar la industria española por medio de las hilanderas parecía dar lugar a una visión estancada del desarrollo de la industria, una imagen alejada

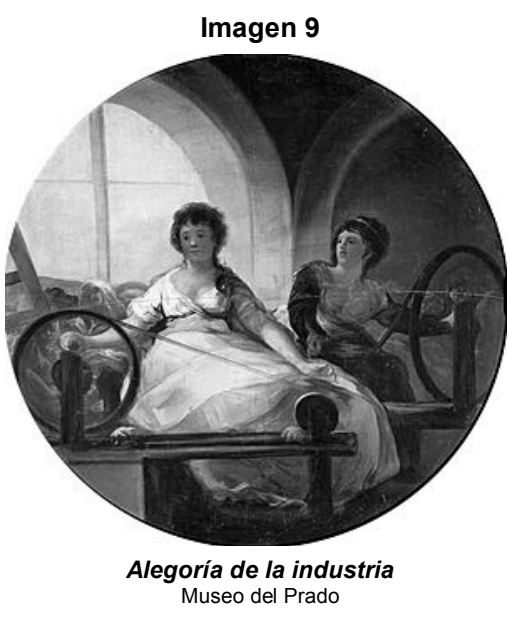
de la evolución industrial que moderadamente se estaba produciendo en algunas áreas de la España del siglo XVIII. Aunque la actividad industrial seguía siendo muy débil en la España interior, la producción de la industria se incrementó, los Borbones hicieron esfuerzos de fomento (fábricas reales, protección, exenciones y franquicias...) y aparecieron nuevos capitales y nuevas formas de organizar las actividades productivas, especialmente en Cataluña, Valencia y el País Vasco. ${ }^{30}$ En el cuadro de Goya no hay alusión a nueva tecnología, ni a la concentración de recursos humanos ni a la división del trabajo. Parecería pues una representación tradicional con poca entidad industrial y que vendría a ser por su debilidad subsidiaria de otras actividades como la agraria. Tendríamos pues a un Goya con escasa visión industrialista, especialmente respecto a la incipiente industria moderna.

Pero en segundo lugar, puede verse la representación desde una perspectiva diferente al considerar las condiciones y mentalidad de la época. El concepto de

${ }^{29}$ La composición es distinta; en el óleo de Velázquez aparecen cinco mujeres en primer plano; de las dos principales sólo una trabaja con una rueca y la segunda con una devanadera (armazón de cañas cruzado, que gira alrededor de un eje vertical). El sentido del cuadro de Velázquez se refiere a La fábula de Atenea y Aracne: una joven Aracne, tejía tan bien que mejoraba a la diosa Atenea, inventora de la rueca.

${ }^{30}$ Llopis (2002 144-45). 
"industria" hay que utilizarlo con precaución para el siglo XVIII, pues posee un significado distinto al de hoy en día (Romano 1976, Maravall 1991). La diferencia no se refiere sólo a la cuantía de la producción, sino especialmente a las formas de la producción, a la organización del trabajo y al papel ocupado por la actividad industrial en el conjunto de la vida económica. La propia palabra "industria" siguió poseyendo en buena medida el significado tradicional de atributo humano (persona industriosa, laboriosa, hábil, instruida...). La expresión poseía un significado heterogéneo de actividades económicas no agrarias de diversas características y con predominio de la dispersión y del pequeño tamaño: industria doméstica, industria rural, industria popular urbana, artes y oficios organizados generalmente en gremios, escuelas de hilados en Sociedades Económicas y hospicios, pequeños empresarios textiles, además de fábricas reales y manufacturas. Una evolución del término analizada con detalle por José Antonio Maravall (1991) para el caso español.

Campomanes y Jovellanos, entre otros ilustrados, insistieron tanto en que el fomento de la industria popular constituía tanto una batalla para desterrar la ociosidad como un medio imprescindible para incorporar a la mujer al proceso productivo, y reconocer frente a los gremios, a las leyes y a otras discriminaciones la libertad del ejercicio del trabajo femenino. ${ }^{31}$ Además propugnaban la importancia del hilado en la industria popular urbana y en la rural. Se trataba de combatir la desocupación de la población y cubrir los tiempos muertos de varias ocupaciones, especialmente en las primeras etapas del proceso productivo textil, en el hilado y torcido del algodón y la lana y también del lino y cáñamo. Eran artes sencillas, de cómodo aprendizaje, de escaso capital requerido y de pronto y fácil despacho. Con elegante retórica Jovellanos (1785) celebraba las excelencias de la actividad hiladora: “¿Qué otro objeto será más digno de sus desvelos [de las Sociedades Económicas] que el fomento del arte de hilar?" Tras destacar sus ventajas al proveer materias primas, al ocupar multitud de manos y al generar una considerable riqueza, concluye en que es sin disputa alguna el arte "más importante y provechoso de cuantos ha inventado la industria de los hombres". Sean o no del todo ponderadas las palabras del asturiano, lo cierto es que sintetizan con vehemencia la visión económica ilustrada predominante sobre el arte de hilar y su importancia en el seno de la industria y de la economía.

Podemos ahora volver a observar el óleo circular de Goya "La industria" considerando la perspectiva ilustrada que podría incluso explicar por qué Goya eligió el tema de las hilanderas como representativo de la industria. La «industria popular urbana» de la que formaban parte las hilanderas constituía un instrumento para la integración (y liberación) de las mujeres en el terreno laboral y para la reconversión del numeroso resto de habitantes «ociosos» en «útiles».

${ }^{31}$ Campomanes (1774-1777) y Jovellanos $(1785,509-514)$ 
Quizá ello es lo que estaba en el trasfondo del cuadro de Goya que representaba esa situación como eco de la mentalidad ilustrada que hemos visto. Además, se promulgaron Reales Cédulas (1779 y 1784), unas frente a los gremios, permitiendo el trabajo femenino de cualquier clase "compatible con el decoro de su sexo", y otra Cédula (1786) estableciendo con carácter general escuelas de hilaza de lana en ciudades y pueblos. ${ }^{32}$

Se ha afirmado que los ropajes de las dos mujeres del óleo de Goya no son los correspondientes a personas humildes, y es cierto. Pero cabe tener en cuenta que Goya, como Campomanes y Jovellanos, no sólo pensaba en las mujeres de alta condición sino en las mujeres ociosas en general, la mayoría de ellas podía constituir fuerza de trabajo. Tampoco contemplaba únicamente el caso de las mujeres en la ciudad, como se desprende de la alegoría de la industria, sino que extendía su concepción al territorio rural. "Esta pobre aprovecha el tiempo" es el expresivo título de un dibujo de Goya en el que aparece una joven pastora sentada frente a sus ovejas y mientras descansa trabaja el hilado utilizando una sencilla rueca y un huso correspondiente. ${ }^{33}$ El hilado es para Goya una útil fórmula para ocupar el ocio de las mujeres de toda condición, para evitar tiempos muertos, y es un medio para su promoción económica y personal, aunque sea modesta. Y todo ello está bajo la perspectiva económica de Goya.

\section{EL COMERCIO: CONFIANZA, COLABORACIÓN Y HEGEMONÍA}

La alegoría sobre el Comercio parece más sencilla de interpretación. Dos hombres realizando anotaciones sobre una mesa representan al comercio. Uno de ellos, de posición más elevada, utiliza un turbante lo que parece indicar el carácter oriental del pequeño establecimiento comercial. Bajo la mesa unos sacos depositados y delante de ellos una cigüeña, animal simbólico (ya que estas aves se ayudan unas a otras), que representando confianza y ayuda mutua en las relaciones entre esas aves. Ambas características se deben extender a las relaciones comerciales entre los hombres. ${ }^{34} \mathrm{Al}$ fondo, en el lado

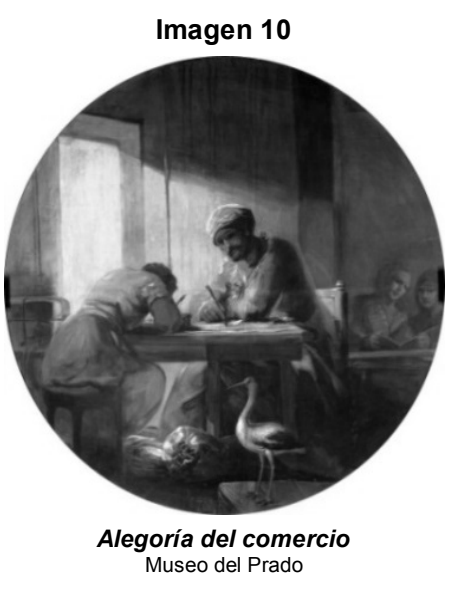

\footnotetext{
${ }^{32}$ Reales Cédulas de 12 de enero de 1779 , de 2 de septiembre de 1784 y de 22 de mayo de 1786 , Novísima recopilación, libro VIII, título XXIII, leyes XIV y XV, y Real Cédula de 22 de mayo de 1786, Novísima recopilación, libro VIII, título XXIV, ley VIII, pp. 191-192.

${ }^{33}$ Goya, "Esta aprovecha el tiempo", Dibujo C11, 1803-1824, aguada de tinta china, colección particular, Nueva York.

${ }^{34}$ Nordström, (1962, 120-22).
} 
derecho de la representación, se puede observar otra estancia menor donde dos mujeres hojean un libro ¿Sería un cuaderno de contabilidad o quizá una relación de pedidos?

La imagen goyesca del comercio representa más una dependencia u oficina comercial encargada de organizar y contabilizar los intercambios que una tienda abierta al público. Una representación discreta, ninguna figura humana está idealizada, ningún elemento material sobredimensionado, sino que el cuadro centra toda la atención en la actividad comercial que se registra sobre la mesa. No se refiere al comercio interior sino al internacional, al oriental, que posiblemente tuviera relación con el plan maniqueo de Godoy en 1802 de abrir nuevas rutas comerciales con Marruecos y tierras africanas interiores. ${ }^{35}$ Cabe tener en cuenta que de Godoy fue el encargo del óleo destinado al palacio del Príncipe de la Paz quien llegó a concentrar tropas expedicionarias en Cádiz para atacar y dominar comercialmente a Marruecos. La cigüeña del óleo de Goya no alentaría el fracasado plan ni de haber conocido el pintor aragonés la estratagema bélica del valido hubiera deseado glorificarlo.

\section{TRES ASPECTOS ADICIONALES: OTRAS PINTURAS, CUANTIOSOS RETRATOS Y ÉXITO ECONÓMICO}

Hasta aquí hemos tratado de analizar las principales pinturas de Goya que constituyen el marco general de sus perspectivas económicas. La amplitud de la obra del aragonés y la naturaleza y dimensión aconsejable de este trabajo nos impiden alcanzar, como siempre, una quimérica exhaustividad e incluso una rotunda determinación. Existen imágenes, temas y actividades de Goya que han quedado al margen de nuestra exposición, aunque no cabe duda de que una ampliación y un análisis detallado de los mismos y de su contexto pudieran completar en el futuro el análisis general expuesto.

En particular me refiero a tres cuestiones de la actividad pictórica de Goya y sus consecuencias: pinturas y dibujos no contemplados, los retratos de economistas, políticos y hombres de negocios y los ingresos económicos del pintor. Cada una de ellas podría dar lugar a un trabajo específico. En primer lugar, las pinturas no contempladas son obviamente abundantes. Goya creó diversas escenas de diversiones populares, de temas rurales y costumbristas, de crítica social y del comportamientos individuales, de la Junta de Filipinas y de una variedad de oficios como el cacharrero, las lavanderas y sus "útiles trabajos", el afilador, los cómicos ambulantes, los actores, los trabajadores de una fragua, el albañil herido, los conductores de una gran piedra en una construcción y otras visiones. Un tema que repitió en sus dibujos fue el de la mendicidad -sobre todo la fin-

\footnotetext{
${ }^{35}$ Tomlinson (1993, 131-32).
} 
gida-, la holgazanería y los pobres verdaderos, aunque con somera perspectiva económica.

La segunda cuestión son los retratos que forman una parte considerable de la obra de Goya (más de un 60 por ciento). Goya retrató en un total de 320 pinturas a los reyes y a la corte, a personajes políticos destacados, a mujeres y hombres aristócratas, además de una galería de sus principales amistades y contactos profesionales, a economistas, intelectuales, hombres de negocio y altos funcionarios y a una amplia gama de personas desde cardenales y generales hasta toreros y actrices. Y a él mismo con más de 15 autorretratos. A nuestros propósitos, sería relevante seleccionar y analizar, los retratos con matices económicos del conde de Floridablanca, de Miguel de Múzquiz, del conde de Cabarrús, de Sebastián Martínez, de Gaspar Melchor de Jovellanos, de Francisco Saavedra, de Ramón de Pignatelli, del marqués de San Adrián, de José Luis Munárriz, entre otros, no sólo para poner rostro a estos personajes relacionados con la economía, sino para tratar de descubrir características personales que pudieran afectar a su labor y a la habilidad del pintor. Es un estudio no realizado en su conjunto y esperamos poder ofrecerlo en un plazo no dilatado.

El tercer y último aspecto se refiere a los ingresos económicos de Goya como pintor. Este es un tema típico de la "economía del arte" pero complejo. Los ingresos económicos dependen en buena medida de la demanda de sus pinturas en su propio tiempo. ¿Cuál fue el precio del arte de Goya? La contestación requiere también una investigación específica y general que debería contemplar el alza de los ingresos regulares iniciados en 1775 como pintor de cartones para tapices -después de un periodo inicial, cobraba unos 8.000 reales de sueldo anual- seguidos diez años después como pintor de cámara del rey -15.000 reales- hasta el año 1799 en que alcanzó el grado más elevado de primer pintor de cámara -50.000 reales más 500 escudos para carruaje-, retribución que en 1825 consiguió convertir en pensión anual de jubilación.

Habría que contemplar después los ingresos variables que provienen principalmente de los cartones para tapices (que cobraba entre 2.000 y 3.000 reales, aunque por alguno, valorado individualmente, llegó a cobrar 8.000 reales), de los retratos y de los encargos de instituciones, especialmente religiosas (valorados éstos entre unos 10.000 y 30.000 reales). Y a distancia otras ventas como los Caprichos (a 320 reales por serie, pero sólo se vendieron 27 antes de ser retiradas), láminas de la tauromaquia y algunos dibujos.

El precio de los retratos de Goya fue el más elevado en su época. Naturalmente variaba de unos personajes a otros (podríamos estimarlos entre 4.000 y 15.000 reales por retrato) pero hay bastantes de ellos en los que el precio no está documentado. ${ }^{36}$ La especialista Jeannine Baticle indica que entre 1803 y 1807

${ }^{36}$ Algunas datos dispersos sobre ingresos económicos en Baticle (1992) y en Alcalá (1988). 
Goya pintó, al menos, treinta retratos, cuyo precio variaba de unos 10.000 reales por una pintura de cuerpo entero y unos 4.000 por un busto. Fueron unos ingresos cuantiosos; depende también de los recursos y del grado social de la persona retratada. El retrato de Jovellanos de 1798 alcanzó un precio de 6.000 reales, ${ }^{37}$ el del rey, encargado en 1787 por el Banco de San Carlos, 10.000, y por dos retratos en 1783 del Infante Don Luis y familia 30.000.

Habría que especificar en un trabajo futuro cómo Goya fue un pintor de éxito económico y artístico en su época. Ciertamente, tuvo un nivel elevado de ingresos que permitió una vida desahogada a él y a su familia, excepto en algunos momentos de la guerra de Independencia y el reinado de Fernando VII. Una característica a considerar es que no fue un pródigo derrochador sino más bien un sobrio previsor con el objetivo de conseguir de su capital unas rentas, que le permitieran vivir y trabajar sin problemas económicos. Sus principales gastos de inversión fueron: en 1780 al adquirir una doble renta vitalicia del Estado (por 60.000 reales al 9 por ciento); tres años después al comprar 15 acciones del Banco de San Carlos por 30.000 reales; en 1800 con ocasión de la venta judicial de bienes eclesiásticos consiguió un inmueble para residencia familiar de cuatro alturas en el centro de Madrid por unos 200.000 reales (no hay acuerdo en la

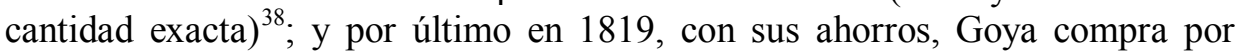
60.000 reales la finca que se conoce con el nombre de la Quinta del Sordo, junto al río Manzanares, famosa por acoger en sus paredes las Pinturas negras.

El desarrollo de las tres cuestiones podría ampliar el marco de análisis de las perspectivas económicas de un pintor universal y copiosamente fructífero en sus creaciones artísticas de diversos argumentos. Las perspectivas económicas de Goya son sólo una parte de su obra conjunta y no pensamos ni en la búsqueda sin término de la exhaustividad ni dar por concluida la investigación que debe integrarse con otras.

\section{PARA CONCLUIR: IDEAS ECONÓMICAS Y PROCESO ARTÍSTICO}

En el siglo XVIII la naciente economía política como conocimiento y como programa de acción es sin duda un elemento integrante del fenómeno más amplio de la Ilustración, un ramo del espíritu de reforma que recorrió Europa, especialmente en la segunda mitad del Settecento riformatore según los documentados estudios de Franco Venturi (1969-1990). Ilustración y economía, arte y literatura, filosofía y ciencias naturales, reforma y revolución, dominaron

\footnotetext{
${ }^{37}$ No se sabe con certeza si los 6000 reales corresponden solo al retrato de Jovellanos o a este junto con el de Francisco de Saavedra.

${ }^{38}$ Baticle $(1992,177)$ indica que según el marqués de Saltillo el precio fue de 235.260 reales y según Matilla Tascón de 197.458.
} 
el panorama ilustrado en los diversos campos intelectuales y en algunos casos en el campo político. Las ideas económicas en España se expandieron a lo largo del siglo, y de forma más intensa desde 1780, expresadas en libros, traducciones, publicaciones periódicas, folletos, actas y memorias de las Sociedades Económicas y de las Juntas de Comercio y manuscritos.

Goya y el espiritu de la Ilustración, un volumen colectivo editado con participación de destacados especialistas en 1988, vino a reafirmar y difundir las apreciaciones previas sobre el estrecho lazo intelectual entre el pintor aragonés y los valores de la Ilustración. ${ }^{39}$ Aunque siguen existiendo algunas voces escépticas ante el reduccionismo que pueda suponer esta visión y la excesiva racionalización de las pinturas -Tomlinson (1993, 15-18)- no cabe duda de que la tesis de la existencia de ese marcado lazo intelectual y político cuenta con amplios apoyos. Similitudes entre textos literarios ilustrados e imágenes del pintor (o con las denominaciones de los grabados), contactos en academias y tertulias, relaciones de cercana amistad con destacados ilustrados (L. Fernández Moratín, Meléndez Valdés, Jovellanos, Iriarte, Ceán Bermúdez y otros) y los esmerados retratos de ellos, son los elementos principales que fundamentan en la literatura ese nexo ilustrado.

Pero todo ello no quiere decir que exista necesariamente una identidad entre ideas ilustradas ajenas e imágenes creadas por el pintor. De hecho, el proceso artístico seguido por Goya se puede desarrollar a partir de las observaciones de Glendinning que hemos apuntado en el primer apartado. El proceso tiene un desarrollo en tres momentos. El primero, relativo a las fuentes, se refiere tanto a las ideas e imágenes ajenas o propias como a la realidad económica, social, política y a la mentalidad o vicios de la época, que inspiran inicialmente y a menudo en forma simultánea al autor. El segundo momento es el de los procesos de creación y adaptación con el fin de obtener las imágenes desde las ideas, la imaginación u otros elementos. El proceso de creación es selectivo respecto a los impulsos recibidos y se fundamenta en la imaginación y la habilidad artística y técnica. En el proceso simultáneo de adaptación el artista adecúa la imagen en proceso a lo que desea comunicar, a lo que debía sentir el observador, al destino físico previsto del cuadro o grabado y en su caso a las indicaciones del encargo. $Y$ en el momento final, aparece ya la imagen terminada, y comienza, en su caso, la contemplación y difusión. Es esa imagen última la que debe ser objeto especial de atención más que las fuentes presumiblemente usadas.

Sobre la imagen terminada se dirigía -o se había dirigido- una demanda pic-

${ }^{39}$ Pérez y Sayre (1988). Participan en el libro, entre otros, Jeannine Baticle, Nigel Glendinning, Fred Licht y Teresa Lorenzo de Márquez. 
tórica ${ }^{40}$ que según algunos estudios de la economía del arte podemos ordenarla en tres tipos: una demanda de consumo, que genera una satisfacción al comprador o a quien puede apreciarla en una exposición; en segundo lugar cabe subrayar lo que Thorstein Veblen denominó consumo ostensible del compradorposeedor de la obra al lograr una mayor reputación social, ${ }^{41}$ pudiendo producirse la situación peculiar de que la cantidad demandada del bien ostensible aumente conforme aumenta su precio; y en tercer lugar, la demanda de arte también se puede considerar como demanda de un activo de inversión, dependiendo del riesgo a contraer y las expectativas de revalorización de la obra. Podemos añadir una auto-demanda del autor que deseara conservar algunas obras por motivos personales o por precaución ante acciones represoras.

No es fácil aplicar de forma precisa las categorías señaladas a la obra de Goya. Se debería observar las diferencias entre las obras (en realidad en la pintura no existe un mercado unitario), las características peculiares de los cuadros, y a los motivos de demanda de los compradores, no siempre expresados. Pero la categoría de bienes Veblen de consumo ostensible parece ajustarse a un amplio número de cuadros: retratos de altos personajes, tapices para los palacios reales, imágenes para instituciones eclesiásticas, financieras, académicas y políticas. Así ocurrió con claridad en el caso expuesto de las Alegorías de la agricultura, la industria y el comercio encargadas por un ostentoso Godoy para la bóveda de entrada de su palacio.

Naturalmente la imagen resultante del proceso artístico no es idéntica a las ideas y realidades originales. No hay una copia exacta ni un seguidismo fiel, aunque sí puede existir una sintonía, una correspondencia. En relación con la economía, con la economía ilustrada y el arte de Goya, hay varios puntos de coincidencia, como hemos visto a lo largo de la exposición. La exaltación de la agricultura, la industria popular femenina, el comercio internacional de pequeña escala, la opresión del campesino, la denuncia de las injusticias provocadas por los estamentos sociales privilegiados -la Iglesia y la nobleza-, el apoyo a los trabajos y oficios injustamente deshonrados, la crítica de la mendicidad. Todos estos elementos forman la raíz fundamental que suele alegarse de la influencia de las ideas ilustradas en las imágenes de Goya. Pero también podemos preguntarnos si pudo existir influencia inversa, desde las imágenes e ideas subya-

\footnotetext{
${ }^{40}$ Respecto a la oferta un artista para crear arte necesita de talento, materiales o insumos y tiempo. El talento se tiene o se puede alcanzar, y es difícilmente agotable. Los insumos pueden suponer una parte relevante del costo final de la obra, por ejemplo una obra de teatro, una escultura, pero también pueden representar una parte muy pequeña, por ejemplo los materiales de un cuadro de Goya pueden costar muy poco en relación al precio de la obra. No obstante, muchos artistas incluyen los costos de materiales dentro de los gastos cotidianos (como a menudo hizo Goya). De este modo, un recurso escaso esencial para la toma de decisiones económicas en el lado de la oferta sería el tiempo.

${ }^{41}$ Veblen $(1899,46-62)$.
} 
centes del pintor a los ilustrados y a sus concepciones. No cabe descartar esta posibilidad, entre otras razones, pues muchas de las imágenes de Goya eran fuertemente expresivas, alcanzaron amplia difusión y fueron muy apreciadas por los ilustrados. En cualquier caso, la imprecisa cuestión de las "influencias" no debe conducir a planteamientos extensivos e integrales sobre la circulación de las ideas sino a análisis de casos concretos que puedan obtener resultados determinados. Es necesario no confundir difusión e influencia determinante de las ideas (Lluch y Almenar, 2000) y considerar que alguien que formula una idea puede ser a su vez receptor de otras ideas similares anteriores e incluso que un receptor puede desarrollar las ideas originales en un sentido creador.

En el anuncio publicado en el Diario de Madid el 6 de febrero de 1799 en el que Goya presentaba las estampas de asuntos caprichosos, el pintor reflexiona sobre la cuestión de la originalidad y de la copia a otros autores e incluso a la copia de la naturaleza. Aunque relativas a los Caprichos las reflexiones se pueden extender a otras parcelas de su obra. Goya explica desde el principio del anuncio que se propone la censura de los errores y vicios humanos, objeto hasta entonces de la poesía o de la elocuencia (Helman 47-50). Insiste en "que el autor, ni ha seguido los exemplos de otro, ni ha podido copiar tampoco de la naturaleza", Y termina afirmando que:

La pintura (como la poesía) escoge en lo universal, lo que juzga más a propósito para sus fines: reúne en un solo personaje fantástico circunstancias y caracteres que la naturaleza presenta repartidos en muchos, y de esa combinación... adquiere un buen artifice, el título de inventor y no de copiante servil.

Las perspectivas económicas de Goya fueron naturalmente perspectivas propias del pintor. Él mismo indica que no se desarrollaron en un proceso simple de imitación o copia. Tampoco se reconocía como un mero transcriptor de ideas ajenas en imágenes artísticas propias, sino como un artista creador e inventor en sus pinturas y grabados. Fue un notable personaje de su época, cercano al mundo político como pintor cortesano de donde pudo extraer indicios para pinturas y grabados. Perteneciente al mundo artístico desde la Academia de San Fernando y otras instituciones que le pudieron servir como estímulo. Interesado en el mundo económico tanto por sus inversiones particulares como por la situación económica general, la miseria, el vicio y la desigualdad. Y en contacto personal con los principales ilustrados españoles, con lo que podemos llamar espíritu o estilo de la Ilustración. Cabe subrayar que el arte y la cultura de una sociedad en una época dada, como la de la Ilustración, es un sistema activo de vasos comunicantes que se irradian e influyen unos a otros. Es imposible, al menos en el caso de Goya, reducir ese conjunto de acciones y reacciones a un determinismo estricto, a una influencia decisiva al margen del conjunto del sistema interconectado. El análisis parcial encuentra sus limitaciones. 
Las perspectivas artísticas de Goya nacieron y se desarrollaron en ese ambiente y sistema cultural que forman los medios sociales y personales que enmarcan el surgimiento y avance de las pinturas. Y las perspectivas económicas, plasmadas en cuadros, grabados y dibujos, no surgieron mecánicamente de una influencia determinante de Jovellanos, Meléndez Valdés, Fernández Moratín, Ceán Bermúdez, u otros. Sin ese tipo de influencia varias de sus perspectivas podrían haber brotado. Es cierto que Goya se relacionó con los ilustrados, que intercambió ideas e informaciones, que quizá leyó alguno de sus escritos y que coincidieron todos ellos en numerosas ideas ilustradas, algunas más desarrolladas que otras, y algunos de ellos más expertos que otros en economía. Pero reconocer estos hechos, reconocer una sintonía de ideas como hemos viso y reconocer algunos estímulos iniciales en el dilatado proceso artístico creativo no supone considerar a Goya como mero receptor pasivo de las Luces, como un mero transcriptor artístico de las ideas económicas de los pensadores ilustrados. El pintor aragonés se erigió él mismo como activo creador de imágenes, como tenaz emisor de luces y penumbras en el mundo de la Ilustración.

\section{REFERENCIAS BIBLIOGRÁFICAS}

ALCALÁ FLECHA, ROBERTO (1988). Literatura e ideología en el Arte de Goya. Zaragoza: Diputación General de Aragón.

ARGEMÍ D’ABADAL, LLUÍS (1988). Agricultura e llustración. Antología del pensamiento agrario ilustrado. Madrid: Ministerio de Agricultura, 1988.

ARNAIZ, JOSÉ MANUEL (1987). Francisco de Goya. Cartones y tapices. Madrid: Espasa-Calpe.

BATICLE, JANNINE (1992). Goya, Barcelona. Crítica: 1995.

BAUMOL, WILLIAM and WILLIAM BOWEN (1966). Performing Arts: The Economic Dilemma. New York: The Twentieth Century Fund.

BLAUG, MARK, (ed.). The Economics of the Arts: Selected Readings. London: Martin Robertson, 1976.

CAMPOMANES, PEDRO RODRÍGUEZ (1774-1775). Discurso sobre el fomento de la industria popular y Discurso sobre la educación popular de los artesanos y su fomento. Reproducción facsimilar en Campomanes: IFES, KRK, 2008.

FREY, BRUNO (2000). La economía del arte. Barcelona: Caja de Ahorros y Pensiones de Barcelona.

GARCÍA SANZ, ÁNGEL (1996). "La reforma agraria de la llustración". En A. García Sanz, y A. J. Sanz Fernández (eds): Reformas y políticas agrarias en la historia de España. Madrid: Ministerio de Agricultura, 161-200.

GASSIER, PIERRE Y WILSON, JULIET (1974). Vida y obra de Francisco de Goya. Barcelona: Editorial Juventud. 
GINSBURGH, VICTOR AND PIERRE-MICHEL MENGER, (eds.) (1996). Economics of the Arts. Selected Essays. Amsterdam: North Holland.

GLENDINNING, NIGEL (1992). Goya. La década de los caprichos. Retratos (17921804). Madrid: Real Academia de Bellas Artes de San Fernando.

GLENDINNING, NIGEL (2008). Arte, ideología y originalidad en la obra de Goya. Salamanca: Universidad de Salamanca.

GOODWIN, CRAUFURD (2006). "Art and Culture in the History of Economic Thought". En V. Ginsburgh y D. Throsby (eds.): Handbook of the Economics of Art and Culture. Amsterdam: Elsevier.

GUDIOL, JOSÉ (1970). Goya, 1746 -1828. Biografía, estudio analítico y catálogo de sus pinturas, 4 vols. Barcelona: Polígrafa.

GUERCI, LUCIANO (1988). L'Europa del'Settecento. Permanence e mutamenti. Milano: UTET.

HELMAN, EDITH (1970). Jovellanos y Goya. Madrid: Taurus.

HELMAN, EDITH (1986). Trasmundo de Goya. Madrid: Alianza Editorial.

JOVELLANOS, GASPAR MELCHOR (1785). "Informe a la Junta General de Comercio y Moneda sobre el libre ejercicio de las artes". En Jovellanos: Escritos económicos, Madrid, Real Academia de Ciencias Morales y Políticas, 2000, 431-466.

JOVELLANOS, GASPAR MELCHOR (1795). Informe de la Sociedad Económica de esta Corte al Real y Supremo Consejo de Castilla en el Expediente de Ley Agraria, Extendido por su individuo de número el $S^{r}$. D. Gaspar Melchor de Jovellanos, a nombre de la Junta encargada de su formación, y con arreglo a sus opiniones. Con Superior Permiso. Madrid: en la Imprenta de Sancha, Impresor de la Real Sociedad. Año de MDCCXCV.

LAFUENTE FERRARI, ENRIQUE (1947). Antecedentes, coincidencias e influencias del arte de Goya. Madrid: Sociedad Española de Amigos del Arte,

LLOMBART, VICENT (2000). "El pensamiento económico de la llustración en España, 1730-1812". En Fuentes Quintana, E. (dir.): Economía y economistas españoles. 3. La llustración. Barcelona: FUNCAS y Círculo de Lectores, 7-89.

LLOPIS, ENRIQUE (2002). "Expansión, reformismo y obstáculos al crecimiento". En Francisco Comín, Mauro Hernández y Enrique Llopis (eds.): Historia Económica de España, Siglos X-XX. Barcelona: Crítica, 121-192.

LLUCH, ERNEST y SALVADOR ALMENAR (2000). "Difusión e influencia de los economistas clásicos en España (1776-1870)". En Enrique Fuentes Quintana (dir.): Economía y economistas españoles, 4, La economía clásica. Barcelona: FUNCAS y Círculo de Lectores, 2000, 93-170.

LORENZO ÁLVAREZ, ELENA DE (2002). Nuevos mundos poéticos: la poesía filosófica de la Ilustración. Oviedo: Universidad de Oviedo, Instituto Feijoo de Estudios del siglo XVIII.

MARAVALL, JOSÉ ANTONIO (1991). Estudios de la historia del pensamiento español (siglo XVIII). Madrid: Mondadori.

MELÉNDEZ VALDÉS, JUAN (1820). Poesía de Don J. M. V. Madrid: Imprenta Real, 4 vols.

NORDSTRÖM, FOLKE (1962). Goya, Saturno y melancolía. Consideraciones sobre el arte de Goya. Madrid: Visor, 1989. 
OCAMPO SUÁREZ-VALDÉS, JOAQUÍN (20010). “Jovellanos: ilustración, economía y 'felicidad pública". Cuadernos dieciochistas, 11, 93-117.

ORTEGA Y GASSET, JOSÉ (1966). Goya. Madrid: Editorial Revista de Occidente.

PALMA, LUIS ANTONIO y LUIS FERNANDO AGUADO (2010). "Economía de la cultura, una nueva área en especialización en la economía". Revista de economía institucional, 12(22), 129-165.

PÉREZ SÁNCHEZ, ALFONSO EMILIO y ELEANOR SAYRE, (eds.) (1988). Goya y el espíritu de la llustración. Madrid: Museo del Prado. (Edición inglesa: Goya and the Spirit of Enlightenment. Boston: Museum of Fine Arts, 1989).

ROBLEDO, RICARDO (1993). Economistas y reformadores españoles: la cuestión agraria (1760-1935). Madrid: Ministerio de Agricultura, Pesca y Alimentación.

ROMANO, RUGGIERO (1976). Industria: storia e problema. Torino: Einaudi.

ROSE DE VIEJO, ISADORA (1984). "Goya's Allegories and the Sphinxes: Comerce, Agriculture, Industry and Science in situ". The Burlington Magazine, CXXVI, núm. 970, 34-39.

SEBASTIÁN AMARILLA, J. A. (2004). "La agricultura española y el legado del Antiguo Régimen (1780-1855)". En Llopis, E. (ed.): El legado económico del Antiguo Régimen en España. Crítica: Barcelona, 147-186.

STEIN, JOHN PICARD (1977). "The monetary appreciation of paintings". Journal of Political Economy, 85:1021-1035.

THROSBY, DAVID (1994). "The production and consumption of the arts: A view of cultural economics". Journal of Economic Literature XXXII, 1-29.

TOMLINSON, JANIS A. (1993). Goya en el crepúsculo del Siglo de las Luces. Madrid: Cátedra, 1993.

TORRALBA SORIANO, FEDERICO (1980). Goya. Economistas y banqueros. Zaragoza: Banco Zaragozano.

UGARTE, DAVID De (2000). Microeconomía del arte y la pintura. Madrid, España. Edición digital: http://david.lasindias.com/gomi/documentos/microeconomia_del_arte_y _pintura.pdf

VEBLEN, THORSTEIN (1899). Teoría de la clase ociosa. México: FCE, 1974.

VENTURI, FRANCO (1969-1990). Settecento riformatore. Torino: Giulio Einaudi, 5 vols.

WILSON-BAREAU, JULIET (1992). Goya: la década de los caprichos: dibujos y aguafuertes. Madrid: Real Academia de Bellas Artes de San Fernando. 